\title{
LIQUID CHROMATOGRAPHY-MASS SPECTROMETRY ANALYSIS OF FRUITS OF AN ECONOMICALLY IMPORTANT PLANT SCHISANDRA CHINENSIS BAIL. FROM CHINA AND EAST RUSSIA
}

\author{
LUFEROV AN ${ }^{1}$, KARTASHOVA NV ${ }^{*}$, STRELYAEVA AV ${ }^{1}$, KUZNETCOV RM $^{2}$ \\ ${ }^{1}$ Department of Pharmacognosy, FGAOU VO First Moscow State Medical, University named after I.M. Sechenov Ministry of Health of the \\ Russian Federation, ${ }^{2}$ Laboratory of Pharmacokinetics and Metabolomics Analysis, FGAOU Vo First Moscow State Medical University \\ named after I.M. Sechenov Ministry of Health, Russian Federation. Email: nataliekartashova@gmail.com
}

Received: 14 December 2017, Revised and Accepted: 2 May 2018

ABSTRACT

Objective: The study was carried out with an objective to characterize the possible bioactive phytochemical constituents from fruits of Schisandra chinensis Bail. by liquid chromatography-mass spectrometry analysis.

Methods: Plant material was collected from Schisandra chinensis during August-October. The dried plant fruits were extracted with solvents using ethanol 95\% extractor. The results of chromatography-MS analysis performed on the instrument Agilent Technologies established the presence of major and minor components. It was conducted a qualitative and quantitative comparison of infusions using software ChemStationE 02.00 and full library of mass spectra NIST 05.

Keywords: Chromatography, Composition, Schisandra chinensis.

(C) 2018 The Authors. Published by Innovare Academic Sciences Pvt Ltd. This is an open access article under the CC BY license (http://creativecommons. org/licenses/by/4. 0/) DOI: http://dx.doi.org/10.22159/ajpcr.2018.v11i9.24272

\section{INTRODUCTION}

Schisandra (Schisándra chinénsis Bail.), family Schizandraceae, is a medicinal plant that is widely known in traditional and folk medicine. With a history of use in Chinese medicine has about 15 centuries, and this plant takes the second place on popularity after ginseng [1]. Schisandra is native to China, Japan, and Korea. On the territory of Russia is found in the Primorsky and Khabarovsk territories, Amur region, Sakhalin, and the Kuril Islands (Shikotan, Kunashir). Schisandra can grow on poor podzolic loam and sandy loam floodplain soils. Optimal for growth and fruiting is drained soil of the valleys of small mountain rivers and streams.

Schisandra chinensis is widely used as medicinal plants with tonic and adaptogenic action.

The first studies on the chemical composition of Schisandra chinensis were conducted in the 30-40-ies of the fruit were found citric, tartaric, and malic acids, essential oils, and sugary substances in the seeds - up to $50.44 \%$ oil, including 5.75\% natural and related substances. Later, in 1951, D. A. Balandin described a method of obtaining from seed clean individual substances, the use of which in the equivalent feedstock doses, enabling them to play a stimulating and other effects caused by drugs. - Schisandrine, one of the main lignans (BASS lemongrass). Lignans - phenolic dimeric compounds consisting of two phenylpropanoid fragments (C6-C3) connected between the b-carbon atoms of the side chains. They are soluble in fat, essential oils and resins. Lignans are not distilled with water vapor. Ultraviolet rays cause blue or yellow glow. The term "Lignan" was first introduced Heartcom in 1936. At this point in the Schisandra lignans identified about 30 that were accumulated in all organs. The fruit contains lignans (0.73-5.7\%), while the highest content is found in the skin of the pericarp. Essential oil $(60 \%)$ represented by the following components: Sesquiterpenes; $13.5 \%$ of monocyclic terpenes; $4 \%$ - aliphatic; more than $3 \%$ - bicyclic terpenes number pinana; and $4,6 \%$ - number of Campana. The composition of essential oil presents sesquiterpene, $(+) \alpha$-ilagan, $\alpha$ - and $\beta$-chamigrene, chamigrene, bornyl acetate (9.2\%), and otoxicity (about 2\%), giving the essential oil of lemongrass is very pleasant aroma and distinctive bitter taste. In the fruit of Schisandra chinensis contains a fatty oil (33.8\%) represented by the following acids: Oleic (28.5-34.1\%), linoleic (of 55.9-59.8\%), and resin $(8.7 \%)$. In addition, juicy pericarp of the fruit of the organic acids were detected - citric (11\%), apple (10\%), wine $(2 \%)$; oxalic, succinic, pectin, Vitamin C (500 $\mathrm{mg} \%), \mathrm{P}, \mathrm{E}$; tannins $(0.11-0.33 \%)$, carbohydrates (to $9.5 \%$ ). The seeds contain lignans (0.73-5.16\%), while the share of schisandrine and $\gamma$-schisandrine ratio is $1.2-4.3 \%$ and essential oil (1.6-2.0\%) and fatty oil (of 20.0-23.9\%) [2]. In the course of histochemical analysis, it was found that - essential oil, lignans, pigments, wax, and other substances are held in a rigid sheath (husk) of the seeds. Its lignans are $1.12-5.02 \%$ and catechins of $0.8-1.63 \%$. The content of lignans is increased as fruit ripening. In the fatty oil, the presence of more than $2 \%$ essential oil, about $8 \%$ of the lignans, $1 \%$ pigment, $0.1 \%$ sterols, $0.0012 \%$ of tocopherols, and $0.5 \%$ of wax and free fatty acids - palmitic, myristic, stearic, oleic, linoleic, and palmitic and oleic acids. In the endosperm of the seed contains only lipids, glycerides of unsaturated fatty acids, sterols, tocopherols, and proteins $[3,4]$.

\section{METHODS}

Chromatography-mass spectrometric analysis was carried out on the instrument company Agilent Technologies consisting of 7890 gas chromatograph (column HP-5, $50 \mathrm{MX} 320 \mu \mathrm{m} \times 1.05 \mu \mathrm{m}$ ) and mass - selective detector $5975^{\circ} \mathrm{C}$ quadrupole mass analyzer; a temperature program of chromatographically: $40^{\circ} \mathrm{C}$ isotherm $2 \mathrm{~min}$, then programmed heating up to $250^{\circ} \mathrm{C}$ at a rate of $5^{\circ} \mathrm{C} / \mathrm{min}$ and at $250^{\circ} \mathrm{C}$ isotherm for $15 \mathrm{~min}$; and further programmable heating up to $320^{\circ} \mathrm{C}$ at $25^{\circ} \mathrm{C} / \mathrm{min}$ and $320^{\circ} \mathrm{C}$ isotherm 5 min injection 1 ál. The injector with the division of the flow of $1: 50$. Injector temperature $250^{\circ} \mathrm{C}$. the interface Temperature $280^{\circ} \mathrm{C}$. Carrier gas helium, flow rate $1 \mathrm{~mL} / \mathrm{min}$. Full scan total ion current was performed. Software - ChemStationE 02.00 [4]. Identification of the component composition (qualitative analysis) was performed according to the full library of mass spectra NIST 05 and the corresponding values of the linear chromatographic index Kovacs. The 
Table 1: The main components identified in ethanol extract of Schisandra fruit

\begin{tabular}{|c|c|c|c|c|}
\hline No. pic & Name of the compound & RT & Area \% & Formula \\
\hline 1 & A-Pinene & 5.147 & 0.215 & \\
\hline 2 & P-Cymene & 6.682 & 0.416 & \\
\hline 3 & Limonene & 6.745 & 0.261 & \\
\hline 4 & $\Gamma$-Terpinene & 7.239 & 0.474 & \\
\hline 5 & Bornyl acetate & 10.693 & 0.686 & \\
\hline 6 & Apple acid & 10.932 & 1.716 & \\
\hline 7 & Ylangene & 11.888 & 1.869 & \\
\hline 8 & B-Longipinene & 12.916 & 0.167 & \\
\hline 9 & A-Calacorene & 13.867 & 0.130 & \\
\hline 10 & A-acorenol & 14.000 & 0.167 & \\
\hline 11 & Ylangenol & 14.812 & 0.477 & \\
\hline 13 & $\Gamma$-himachalene & 15.915 & 0.274 & \\
\hline
\end{tabular}


Table 1: (Continued)

\begin{tabular}{lllll}
\hline No. pic & Name of the compound & RT & Area \% & Formula \\
\hline 14 & Longipinocarvone & 16.071 & & \\
& & & &
\end{tabular}

relative content of components of the mixture (quantitative analysis) was determined by calculating the ratio of areas of chromatographic peaks (by simple normalization) [5,6]. Object of study is the alcohol extract of the fruits Schisandra chinensis. From fruits were obtained the alcoholic extract. We used extractant ethanol 95\% [7]. Fruits were placed in a flask alcohol in a ratio of $1: 10$, reverse connected to the refrigerator and extracted within $6 \mathrm{~h}[6,8]$.

\section{RESULTS AND DISCUSSION}

Liquid chromatography-mass spectrometry analysis of fruits of Schisandra with solvents using ethanol 95\% extractor revealed 15 main peaks in chromatogram (Table 1) active compounds, respectively. Confirmation of these compounds was based on their retention time, molecular formula, and molecular weight. These bioactive compounds show various biological activities that have been reported earlier. Medicinal plant-based drugs exhibit several broad-spectrum activities [6].

\section{CONCLUSION}

GC-MS study has exploited the potential of Schisandra chinensis. This plant can be a good source of phytoconstituents such as citric, tartaric, and malic acids, essential oils, lignans, sterols, tocopherols, and proteins.

Ethicolegal issues require further discussions and considerations before practical use.

\section{ACKNOWLEDGMENT}

The authors would like to grateful to the Department of Pharmacognosy, First Moscow State Medical University named after I.M. Sechenov, Moscow, for providing infrastructure and instrumentation facilities.

\section{AUTHOR'S CONTRIBUTION}

A.N. Luferovand A.V. Strelyaeva conceived of the presented idea. A.V. Strelyaeva developed the theory and performed the computations. N.V.
Kartashova and R.M. Kuznetsov verified the analytical methods. All authors discussed the results and contributed to the final manuscript. N.V. Kartashova and R.M. Kuznetsov carried out the experiment. N.V. Kartashova wrote the manuscript with support from A.N. Luferov and A.V. Strelyaeva.

\section{CONFLICTS OF INTEREST}

Aurthors have no conflicts of interest to declare.

\section{REFERENCES}

1. Studentsov EP, Ramsh SM, Kazurova NG, Neporozhneva OG, Kochina TA, Voronkov MG, et al. Adaptogens and related group of drugs -50 years of searching. Rev Clin Pharmacol Med Ther 2013;11:3-43.

2. Chikov PS. Atlas of Areas and Resources of Officinal Plants of the USSR. Moscow: Principal Office of Geodesy and Cartography; 1980. p. 340.

3. Kolbasina EI, Solonin EI. Perspective use of Schisandrachinensis (Bail.) as a food and medicinal raw materials. Chem Comput Simulation Butlerov Commun 2001;5:10-2.

4. Samylina IA, Streljaev AV, Lazareva NB, Sadykov VM. Homoeopathic Preparations of the Pharmacopoeia of Medicinal Plants: A Training Manual. Moscow: Medical Information Agency; 2012. p. 432.

5. Jaafar NS, Hamad MN, Abbas IS, Jaafar IS. Qualitative phytochemical comparsion between flavonoids and phenolic acids contents of leaves and fruits of Melia azedarach (Family: Meliaceae) cultivated in iraq by HPLC and HPTLC. Int J Pharm Pharm Sci 2016;8:242-50.

6. Waksmundzka-Hajnos M, Oniszczuk A, Szewczyk K, Wianowska D. Effect of sample preparation methods on the HPLC quantitation of some phenolic acids in plant materials. Acta Chromatogr 2007;19:227-37.

7. Maheshkumar SK, Kirti SL. Determination of total flavonoids content and quantification of rutin in momordicatuberosa (Roxb) Cogn. fruits by RP-HPLC. Asian J Tradit Med 2012;7:220.

8. Muchtaridi M, Suryani D, Ali Qosim W, Saptarini NM. Quantitative analysis of $\alpha$-mangostin inmangosteen (Garcinia mangostana L.) pericarp extracts from four districts of west java by HPLC method. Int J Pharm Pharm Sci 2016;8:232-6. 